\title{
P-11 MESOZOIC PETROLEUM SYSTEMS AND PLAYS RELATED TO THE SOUTHERN MOESIAN PLATFORM MARGIN
}

Sofia University, Dept. of Geology, 15 Tzar Osvoboditel Bd., 1000 Sofia, Bulgaria,

\section{Introduction}

The territory of Bulgaria is located on the European continental margin, and covers parts of the northern periphery of the Alpine orogen and its foreland (Moesian Platform).

The Mesozoic-Tertiary evolution of the Southern Moesian Platform margin (SMPM) and the Alpine thrust belt in Eastern Bulgaria was governed by the geodynamic processes in the northern PeriTethyan shelf system. The SMPM was repeatedly affected by Mesozoic rifting cycles that were interrupted and followed by compressional events. A better understanding of the structure and Mesozoic evolution of this area reveals some new prospects for exploration.

\section{Geological Setting}

The Moesian Platform, as the promontory of the European Platform, is separated from the Scythian Platform by the North Dobrogea orogenic belt on its northeastern side. The Platform occupies the southern part of Romania and the northern part of Bulgaria. This mainly Mesozoic Platform is mostly surrounded by the arcuate arc of the Carpathians and Balkans and it extends eastwards to the Black Sea. The geologic boundaries of the Platform are well defined by the leading edge of the surrounding Alpine belts. The Platform is bordered: to the North and West by the Southern Carpathians, which were docking onto the Northern Platform margin during the Middle Miocene with a southerly vergence; to the South - by the Balkan north-vergent thrust-fold belt, were formed during the Eocene. Towards the Black Sea only a broad transitional zone can be outlined where the relatively undeformed platform succession has been downfaulted to the Western Black Sea basin.

Based on recent study (Tari et al., 1997) the numerous Late Triassic Early Cimmerian folds in the Moesian Platform are interpreted as a north-vergent foreland thrust-fold belt. In a wider paleotectonic scenario, this thrust-fold belt represents the frontal part of the Mediterranean Cimmerides propagating into European foreland.

Lately, after detailed and integrated geological-geophysical study calibrated by numerous wells, the Eastern Srednogorie-Balkan rift zone (ES-BRZ) was defined (Georgiev et al., 2000). This zone fringed the Moesian Platform on the South. The ES-BRZ is characterized by several spatially superimposed rifted basins, strongly deformed by multiphase north-verging thrusting during the Early Cimmerian (Late Norian-Hettangian), Mid-Cimmerian (Middle Jurassic), Late Cimmerian (Tithonian), Mid-Cretaceous, Late Senonian and Mid-Eocene compressional events.

Rifting and north-vergent compressional cycles favor trap formation, while the post-rift stages are good for the source rocks deposition.

\section{Petroleum Geology}

Exploration in Bulgaria since 1949 has took place mainly in the foreland (Moesian Platform) of the Alpine orogen and resulted in 30 oil / gas discoveries, but only 12 are economic. Most of the discoveries are located along the transition zone between the Moesian Platform and its Southern margin (Fig. 2). The major reserves are linked to the clastic and carbonate reservoirs of Middle Triassic, Lower Jurassic, Valanginian and Eocene age (Fig. 3). About $75 \%$ of the reserves are 


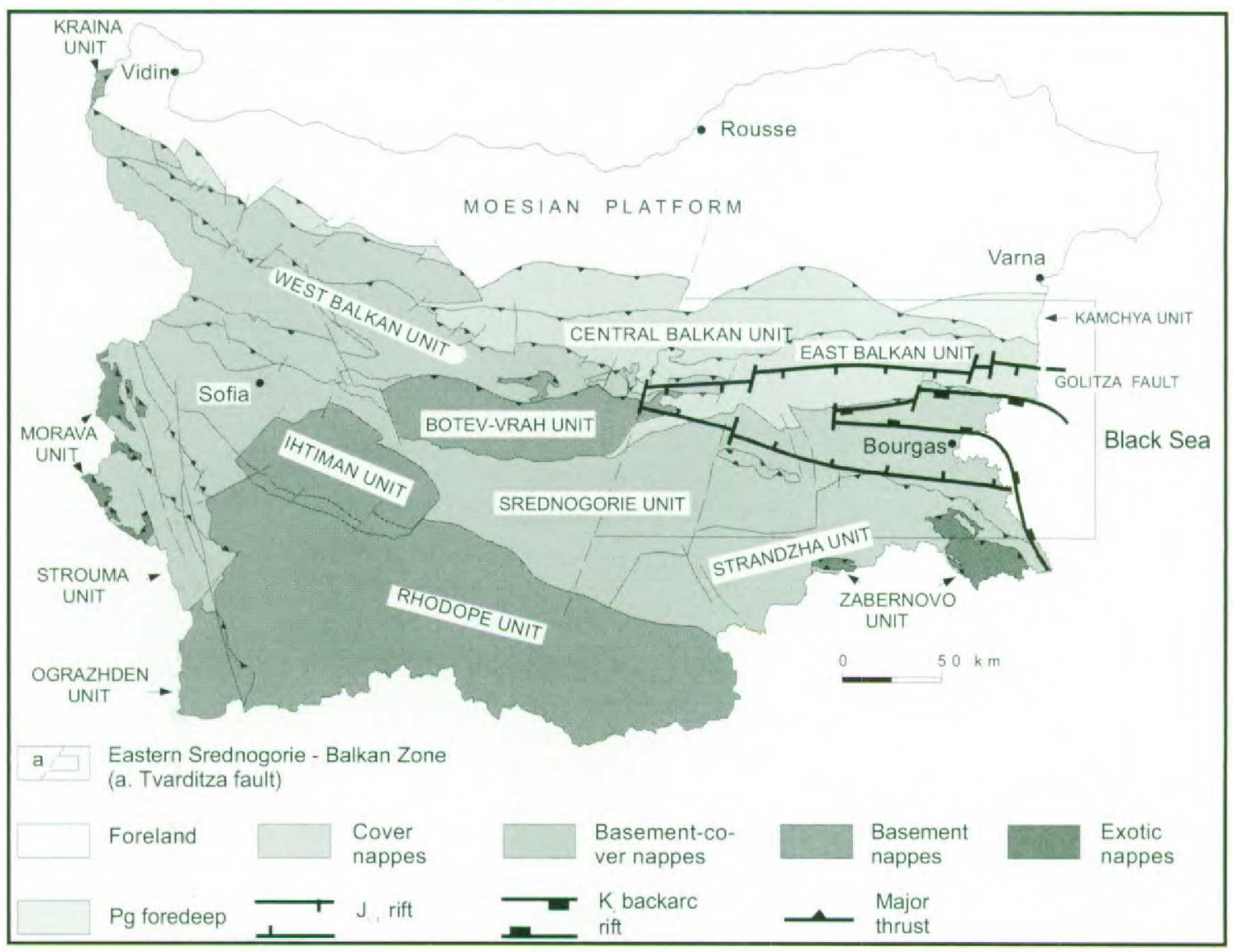

Fig. 1. Tectonic sketch map of Bulgaria (after Tzankov at al., 1996 with modification by Georgiev \& Dabovski, 2000)

related to the unconformities located in the base of the Jurassic, Upper Cretaceous and Middle Eocene, hence the stratigraphic trap reserves dominate notably over anticlinal trap reserves.

Oil-to-oil and oil-to-source correlations, using the biomarkers, shows that the Middle Triassic, Lower Jurassic and Valanginian crude oils share a common source and were most likely generated from the Lower-Middle Jurassic shale and marl (Georgiev, 1998, 2000). This concept is supported also by the distribution of the oil fields: they are located in areas where the LowerMiddle Jurassic sequence is over $200 \mathrm{~m}$ thick. Only then deeper-water shaly deposits are available in this sequence.

The Lower-Middle Jurassic source rocks are thick and wide spread only in the SMPM and in the ES-BRZ. Southward to Balkanides and westward to Lom depression these source rocks thicken and become more mature, because they are more deeply buried.

The geochemical log shows organic-lean source rock in the Lower Anisian and in the Ladinian. Some shale and argillaceous limestone beds are more organic-rich, but are rather thin to generate significant quantities of petroleum.

Onshore Lower-Middle Jurassic source rocks was examined in several wells located in SMPM. When the total Lower-Middle Jurassic tickness increases up to $500 \mathrm{~m}$ and more, the source rocks within them (Etropole and Ozirovo Fms.) have moderate and excellent potential for hydrocarbon generation. The data shows the TOC values vary between $0.8 \%$ and $2.0 \%$, in some cases more, indicating average to above average amounts of organic carbon in these samples. The Rock-Eval data however shows that $S_{2}$ values indicating little to moderate potential for hydrocarbon generation.

The hydrogen index $(\mathrm{HI})$ values are $>200$ indicating that gas-oil prone kerogens appear to be the dominant kerogen type. The HI and $\mathrm{T}_{\max }$ (near and above of $450^{\circ} \mathrm{C}$ ) values suggest that oil has already been generated leaving residual gas potential. Although the potential in the zones near to thrust Balkan front appears to be more gas prone. 


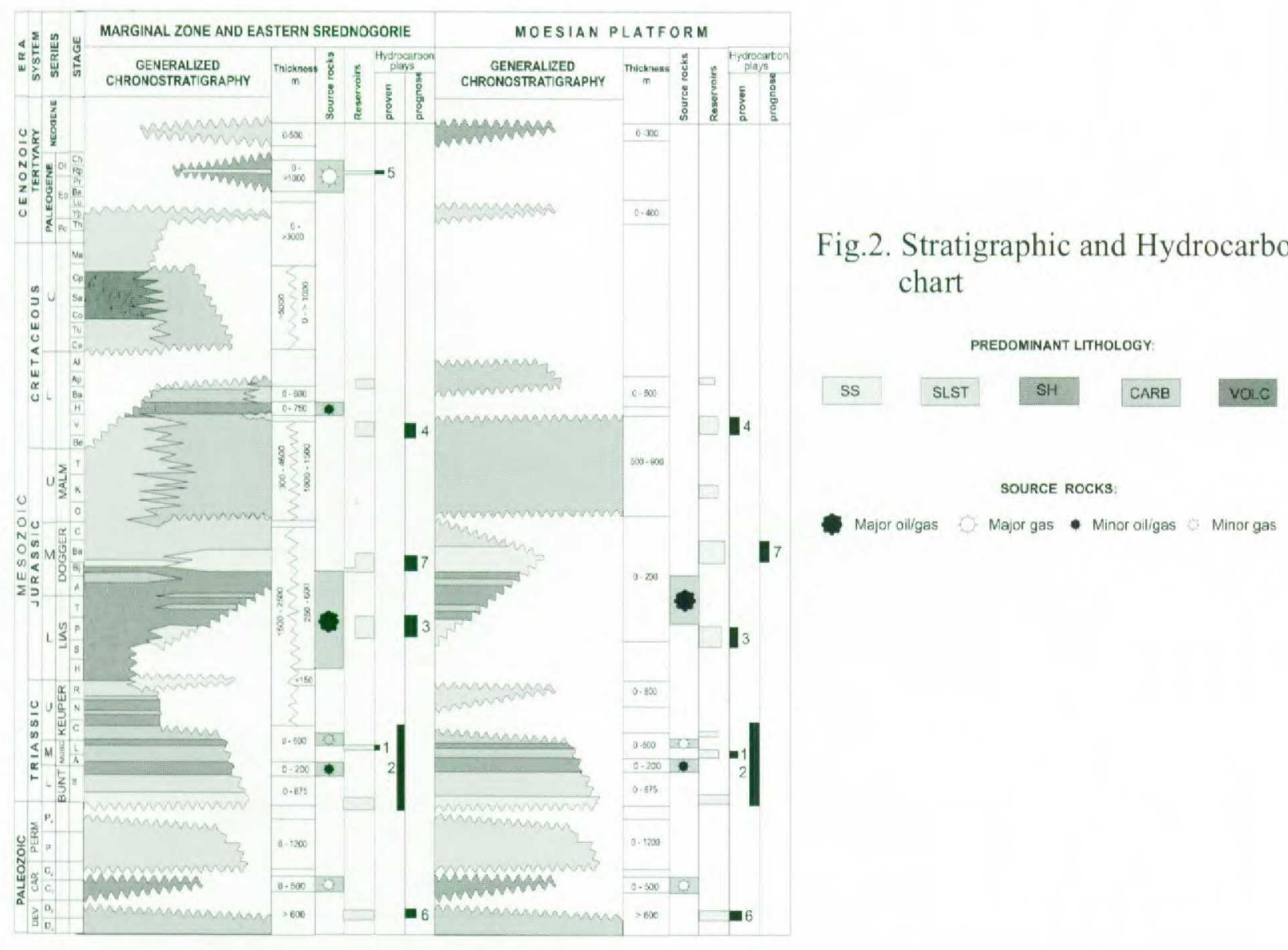

The maturity of the Lower-Middle Jurassic does increase southwards towards the south Moesian platform margin where areas of peak oil $(0.65 \%-0.90 \%$ Ro) through to condensate/dry gas ( 1.3 $\%-2.0 \%$ Ro) maturity occur. Overall, the $\mathrm{T}_{\max }$ values agree with these levels of maturity. The high maturity of the Lower-Middle Jurassic source rocks, however, suggests that significant hydrocarbon generation has taken place.

So, the shale and marl in the lower part of the Lower-Middle Jurassic sequence are the major source interval in the Mesozoic. They have moderate to good potential for both oil and gascondensate generation. Maturity does however increase southwards in platform margin towards the overthrusting frontal zone of the Alpine orogene. Areas of peak oil to condensate maturity occur in the southern platform periphery and beneath of the frontal Alpine thrust sheets, also in the ES-BRZ.

\section{Petroleum Systems and Plays}

Based on the geological/geochemical results three Petroleum systems and seven hydrocarbon plays are defined (Fig. 3, 4). The systems are related respectively to: Lower-Middle Jurassic source rocks; Eocene-Oligocene source rocks and Lower Carboniferous source rocks (Fig. 2). In the Lower-Middle Jurassic Petroleum system there are three pods of active source rocks, located respectively: in the central-western zone of the SMPM; in ES-BRZ and in the Shabla-Varna trough (offshore) (Fig. 1). The active pod in the Eocene-Oligocene Petroleum system is located in the Kamchya foredeep (mainly offshore) (Fig. 1). The prognose Upper Paleozoic Petroleum system is related with a possible Lower Carboniferous active source pod presence with location in the central part of the Moesian Platform in Bulgaria. The Lower-Middle Jurassic petroleum system and its plays in the ES-BRZ are also prognosis. 


\begin{tabular}{|c|c|c|c|c|}
\hline \multirow[t]{2}{*}{ № } & \multirow{2}{*}{$\begin{array}{l}\text { HYDROCARBON } \\
\text { SYSTEMS }\end{array}$} & \multirow{2}{*}{$\begin{array}{c}\text { SOURCING } \\
\text { BY }\end{array}$} & \multicolumn{2}{|c|}{ HYDROCARBON PLAYS } \\
\hline & & & PROVEN & PROGNOSIS \\
\hline I & PALEOGENE & $\begin{array}{l}\mathbf{E}_{2-3}-\mathbf{O I} \\
\text { Claystone } \\
\text { and Shale }\end{array}$ & $\begin{array}{l}\text { Play 5 - Mid.-Up. Eocene - } \\
\text { Oligocene Sandstone } \\
\text { (strat..\& anticl.traps) }\end{array}$ & \\
\hline \multirow{5}{*}{ II } & \multirow{5}{*}{$\begin{array}{l}\text { TRIASSIC -LOWER } \\
\text { CRETACEOUS }\end{array}$} & \multirow{5}{*}{$\begin{array}{c}\mathbf{J}_{1-2} \\
\text { Shale \&Marl }\end{array}$} & $\begin{array}{l}\text { Play 4 -Valanginian Dolom. } \\
\text { \& Limestone (strat. traps) }\end{array}$ & \\
\hline & & & & $\begin{array}{l}\text { Play } 7 \text { - Middle Jurassic } \\
\text { Sandstone (anticl. traps) }\end{array}$ \\
\hline & & & $\begin{array}{l}\text { Play 3 - Lower Jurassic } \\
\text { Sandstone (strat. traps) }\end{array}$ & \\
\hline & & & $\begin{array}{l}\text { Play } 2 \text { - Lower-Mid.-Up. } \\
\text { Triassic Sandstone, Dolom. } \\
\text { \& Limestone (strat. traps) }\end{array}$ & \\
\hline & & & $\begin{array}{l}\text { Play 1-Mid. Triassic Dolom. } \\
\text { \& Limestone (anticl. traps) }\end{array}$ & \\
\hline III & $\begin{array}{l}\text { DEVONIAN-LOWER } \\
\text { CARBONIFEROUS }\end{array}$ & $\begin{array}{c}\mathbf{C}_{1} \\
\text { Shale \&Marl }\end{array}$ & & $\begin{array}{l}\text { Play 6 - Devonian Dolom. } \\
\text { \& Limestone (strat. traps) }\end{array}$ \\
\hline
\end{tabular}

Fig. 3. Hydrocarbon Systems and Plays in Bulgaria

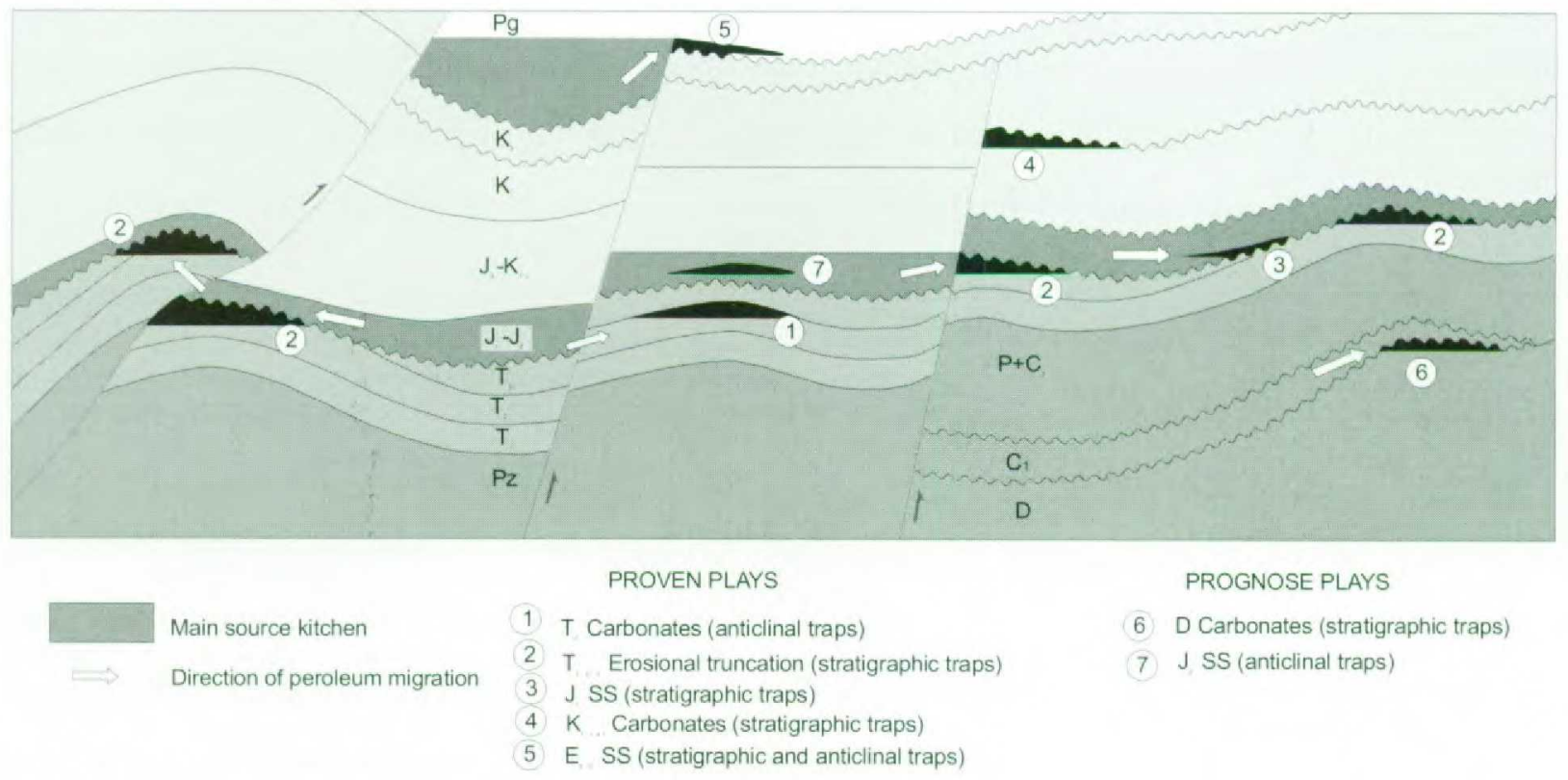

Fig. 4. General play concept

\section{References}

Tari, G., Dicea, O., Faulkerson, J., Georgiev, G., Popov, S., Stefanescu, M. and Weir, G. 1997.

Cimmerian and Alpine stratigraphy and structural evolution of the Moesian platform

(Romania/Bulgaria). - In A. G. Robinson, ed., Regional and Petroleum geology of the Black Sea and Surrounding regions: AAPG Memoir 68, p. 63-90.

Georgiev G. 1998. Hidrocarbon Plays and their prospects in Bulgaria. -in: EAGE $60^{\text {th }}$ Conferece and Technical Exhibition - Leipzig, Petroleum Division, Extended Abstracts, volume 2.

Georgiev G. 1999. Understanding of Petroleum System-Play concept and assessment for Bulgaria , -In:

EAGE $61^{\text {st }}$ Conferece and Technical Exhibition, Helsinki-Finland, Extended Abstracts Volume 2.

Georgiev G. 2000. Oil-Oil and Oil-Source correlation for the major crude oils in Bulgaria. Annuaire de

l'Universite de Sofia "St. kliment Ohridski", Faculte de Geologie et Geographie, livre 1 -

Geologie, t. 92, p. 39-60.

Georgiev G., Dabovski C., Stanisheva-Vassileva, G. 2000. East Srednogorie-Balkan Rift Zone. - In:

Memoir No. 6 of the PeriTethys Programme, P. A. Ziegler, W. Cavazza and A. H. F. Robertson

(eds.) PeriTethyan Rift/Wrench Basins and Passive Margins. Paris. 